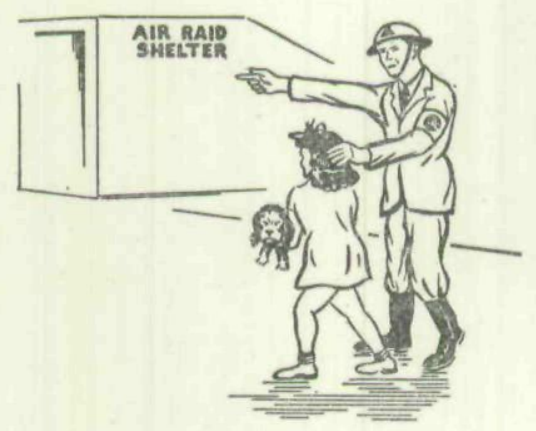




\section{That Our Memory May Be Green}

The IOWA WAR ReCoRDS COMMISsIoN

No tree can grow without roots; and the height of each tree is measured by the length of its underground parts, that which the eye can not see. Likewise, no nation or people can exist without a past. The significance of their future in part depends upon the depth of their understanding of that past. An understanding and an appreciation of history is akin to a constant mobilization of the spiritual and cultural resources to which one is heir. In knowledge and in understanding there is power.

The "past," however, is a relative term. Today will be tomorrow's yesterday; the "present" is merely that interval of time between "what will be," and "what was." In very truth we are living today the future's past. It is a very significant "past," and one full of portents for the tomorrow and the morrow's morrow. We live in an epic period of a world wide civil war.

Happily we recognize that we need not wait until a generation hence to realize the importance of the records of this hour. We know that events do not have to be lost in the shadows of yesteryears to be important historically. But if the future is to know its past, then obviously the records of 'today' must be saved. And saved NOW.

The Iowa State Department of History and Archives is premised upon the conviction that the records of Iowa and her people are at all times worthy of keeping. The proposed Iowa War Records Commission was born of the strength of that conviction. But because the task of securing a complete and adequate record of this crucial era of war is immense, cooperation is needed between the Iowa State Department of History and Archives to collect and save the records, the State Historical Society of Iowa at Iowa City to write of these records in a subsequent day, and the vast number of agencies and organizations scattered over the state to assist in the preservation of the significant records. This cooperation is a dire necessity if the job is to be accomplished. 
It is because this cooperation is needed from all that the Commission has been proposed. This Department firmly believes that Iowa has a challenging opportunity to measure up to a great responsibility. May she achieve the stature required.

There are some, however, who are prone to think that our concern in current war records is "special pleading" on the part of an historian, some believe apparently, that records automatically keep themselves, or that time will winnow only the more essential records (!) or that since we all know and can see what is transpiring why go to the extra trouble of compiling bulky files of common knowledge. This position is in error on several scores. In the first place, and an obvious one, records are saved and history is written against the day when a new generation will arise to whom the causes, events and results of today are not known or understood. A more pernicious error is that which believes the records will keep themselves and that we can gather the information better at a later date. Equally erroneous is the belief that we have not yet created any record of consequence in this era of "Civil War."

Let us not think that to date there is little to record, let us not think that the job can be "as easily" tackled at another and a later time. It is already later than many think.

Twenty-five years ago the United States of America was an active belligerent in the first world war just nineteen months. At the time of this writing over half that time-ten months-has already sped by since Pearl Harbor. Twenty-five years ago Iowa contributed 114,000 men and women to the enlisted services. In ten months Iowa has already exceeded that number in World War II. And even those who read while they run can see that the "home front" of 1917 and 1942 differ in extent and magnitude equal to the difference in the totality of the two wars.

The face of America is changing. So too is the face of Iowa. The changes have come in part gradually, some 
swiftly, some will be temporary, some will be permanent. What the future may be we can not now say with assurance, but all can recognize that we live in a state of flux, that the molds have loosened, that tomorrow will be different. Events are on the march. In terms of people, business, agriculture, education, and physically, Iowa is changing.

Into every community, town, city, and farm of Iowa the war has already reached its harsh hand. Already upon the lap of Mars, the god of war, has been laid the last final sacrifice of nearly 300 Iowans. Four hundred more are reported missing in action. The pupils in more than one Iowa school room recently learned that every one has either a father, brother, or other member of the family in the service of the nation. More than one Iowa community has equalled the Civil War draft on man power, one for each ten of the population, man, woman, and child. And the end is not yet in sight. One Iowa family, the Patton family of Lake Mills, has a father and nine sons enlisted in the Navy; the Brandel family of Dubuque has also given nine sons to the service. In varying degrees similar stories can be told of every Iowa community. Schools, shops, farms, stores, factories are and have bidden farewell to countless young men.

The face of Iowa is changing.

Business men in Iowa towns know the difficulties of hiring help with any assurance that they will remain six months. Some shops are doing twice normal business with half the former help. Restaurants compete for labor, bus stations lose personnel almost before they are trained, girls man oil station pumps. Factories and shops long familiar with civilian lines of merchandise are mobilized for production of war goods exclusively. Shoe merchants discover their men's line dwindling, while their women's sales are sharply rising. Empty automobile show windows call attention to obvious changes, with more portending. A radio equipment supply house is now selling household furniture. Some businesses have shut down. Oil and gasoline stations in many of our cities have closed, others 
bear "for lease" signs on their windows, and wonder what will happen after November. New personnel, less skilled and untrained help, women replacing men at desk, bench, and counter, younger men and older, are but signs of the times.

The face of Iowa is changing.

One sixth of the medical doctors of Iowa have answered the imperative call of the armed forces. Over one-tenth of the of-age lawyers of the state have likewise left their civilian calling. Similar figures are true of other professions. Twelve newspapers have suspended publication, still more operate without their publisher. Schools are losing their teachers, to the army, to war industries, to private employment. Campus and class rooms are geared to wartime schedule. Uniforms dot yard and hall.

The face of Iowa is changing.

Farmers facing increased production demands are confronted with the problem of managing when help formerly required is no longer available. Women, younger children, older men, are slipping into their places behind the plow, the team, the machine. Changes in crops, in marketing, of herds, litters, broods, flocks are to be noted. And one wonders, will there be another aftermath, like the 1920 s?

The face of Iowa is changing.

Iowa cities and towns have added problems of housing, utility service, support. Burlington and the villages and communities within its orbit, Ankeny in central Iowa, and other centers like Ottumwa and Cedar Rapids, face influx of population and increased demands. Other communities face counter difficulties. One Iowa town is reported to have lost 2000 families within the eighteenmonth, and others know to their sorrow the attraction to their working populations of fairer climes and fatter pay envelopes. In some Iowa communities good carpenters are not to be had, in another plumbers are rare, in many the house painter has found steadier work than memory recalls.

One Iowa school room reported that out of thirty-five families represented, twenty-nine mothers were working 
in defense industries or in private employment. Juvenile delinquency is not merely a theory in a number of Iowa communities. And there is surely an impact on Iowa neighborhoods of civilian defense training, with its opportunity for town-meeting types of development.

The face of Iowa is changing.

Tastes are changing too. The new as a criterion of value is being replaced by the "usable." The bicycle may yet outgrow the restriction to the "sport" use class. Advertisements in local papers show a trend in recreation and entertainment significant if not always admirable.

The face of Iowa is changing. Who is there to say that such changes are not significant? Who is there who can now say what direction the changes may next take, how far they will go, and for what good they be made?

C'est le guerre!

A record of this changing scene translated into terms of people, business, work, harvests, and daily living is a part of our present which is and will be the heritage of the future. The present is the warp which woven with the woof of the past produces on the loom of time the pattern of the future.

An understanding of that heritage, is, if rightly comprehended, like possessing a constant inventory of one's resources as a people. Current history recording, therefore, is like keeping a running inventory of your "stock."

II

In normal times the preservation of the current and the past history of Iowa is the responsibility and the obligation of the historical societies of the state, of which this Department is one of the principal two. But these are not normal times. This is war. Since in such crucial eras the record saved should be more than the summary for the state, but should record the story of the locality, for the locality, the magnitude of the task expands and is enlarged.

The record of Iowa in war time concerns two major activities: the military and the civilian front. The former relates to those who have taken the formal oath as en- 
listed personnel in an organized branch of the armed services of the nation. The second includes those who contribute to the success of the first, directly or indirectly and are affected by the course of war activities.

The proposed Iowa War Records Commission is designed simply to preserve the significant records of both activities in Iowa, not only for the "State," but for the local communities as well; it is a means by which all interested organizations in the state, including particularly the local organizations, may join cooperatively in performing this task.

To collect and preserve that community record is not a difficult task, given cooperation.

In each county the Civilian Defense Council, the county libraries, the county historical society, the American Legion posts, the women's service groups, and other organizations of business and farm groups should unite for the task of preserving their war records. Under a capable interested individual as a county chairman, to clear and regulate the traffic of business, each of the cooperating organizations should select a particular phase of the war effort of the county-home or military frontto concentrate upon. With such cooperation the work can be made easy and thorough.

In too few of Iowa's counties is such a program of recording, making, collecting, and preserving the county war history being operated. The most effective piece of work generally is being done whenever the county Civilian Defense Council shares vigorously in the task. One notable example of such an enlightened program in Iowa is that being conducted in Franklin County, under the guidance of R. R. Stuart of the Franklin County Civilian Defense Council. There should be ninety-eight others just as good.

Organized under cooperative leadership as suggested above, each county should first ask itself before entering upon the county war history work: What records will be necessary thirty years from now to adequately and justly describe the total county war effort? To make such necessary records complete three additional questions 
should be put: What was attempted? What was done? How well was it accomplished? One might add a fourth question: Was it worth while?

Obviously each county War Records Unit should also keep in touch with developments in the Iowa War Records Commission program through the Iowa State Department of History and Archives, Des Moines. Appointments of the personnel of that Commission should be expected soon.

Additional help for each county Unit is available in the several bulletins prepared by the Iowa State Department of History and Archives for the Iowa War Records Commission. Each community and county group should procure copies of these bulletins, and study them. The first bulletin explains the purposes and functions of the Iowa War Records Commission, a second details suggested activities for librarians, both as separate institutional projects, and in cooperation with county and local groups. A third bulletin is in preparation outlining details of procedures by which a county War Records Unit may be organized. Other bulletins of help to all groups, and already prepared, may be secured from the WPA War Information Service, State Historical Building, Des Moines. All should be carefully read.

\section{III}

A few suggested activities which every county or local community can undertake when once organized follow:

An enterprise which will appeal to the whole county is a county war roster roll. This is a project with which all will gladly cooperate. Every family will be anxious to list the correct names of its members, all will recognize that the sacrifice of these men and women merits such a record. Through such a universal appeal as a war roster will make to all groups in the county, a start will have been made to secure the necessary support for other enterprises of the County War Records Unit.

The first task in preparing a war roster is to obtain the names of those in the army, navy, marines, coast guard, nurses, WAACs, WAVES, and other auxiliary 
services. The name should be listed on a card or sheet, with the branch of service, date of enlistment, place of residence, and family, with room provided for subsequent changes in rank and station. The names can be secured through cooperation of the county selective service boards, the parents in the county, and the help of the newspapers of the area. From these card-sheets a master alphabetized roll can be prepared, and made ready for public display, on an outdoor bulletin board, in the county court house, or in the library. From such a master county roster each local community can secure its own list.

A second suggestion which the Iowa Department of History and Archives thinks extremely pertinent, and one which will secure a ready support is: "Doughboy Letters." For a soldier or a sailor, next to the boost given in receiving letters from home is a knowledge that the "home folks" are interested in his "daily walk and talk." A county women's service club, or a war veteran's unit should be particularly glad to attend to the first matter, to see that all boys in the county, especially those without living parents or close relatives, receive cards or letters on birthdays, special holidays, and other similar occasions. Such organizations should make a point to see that the local newspaper is supplied with the latest information received concerning the county's enlisted personnel on all the many fronts. Moreover, an extremely appreciated service is the sending of the local paper, particularly when it contains a number of soldier items, to the boys and women in service. These are small items, often overlooked, but important.

"Doughboy Letters" have another aspect, equally important to that above. The boys themselves can help the folks at home. Next to being an observer of the scene is hearing from someone who was. Next to knowing firsthand what present-day army and navy life is like is to hear of it from one who lives it. This is most easily done through letters and diaries written by boys, and men and women, in the services. Men and women in the services could often write more interestingly if they knew 
what they could write about which would interest those to whom their letters are directed.

Therefore, the Iowa State Department of History and Archives, and the Iowa War Records Commission, consider one of the most useful projects a county or local War Records Unit can undertake is this very matter of assisting our men and women in the armed forces of their county to become better letter writers, better "historians," if you please. We have all heard parents remark in explaining a recent letter, "he didn't have much to say, I guess there was not much to write." We should strive to make such explanations impossible. This Department urges every parent, relative, friend, or correspondent of enlisted personnel to impress upon their military correspondents the interest the people at home have in their activities. Such an indicated interest would in many cases give added significance to the military and naval work they are doing.

Each of the state's military men and women should be encouraged to consider themselves as an unofficial Reporter at Large on what transpires at his post or station, on what he himself thinks. Of course there is censorship, there has to be, and should be. But much of keen interest to the people back home is of no concern to the censor: how is the food, how are the clothes, what of the laundry problems at camp and overseas, what recreation facilities are there, the games most popular, how is the camp outfit organized for athletics, who is directing it, and how good is the director, what facilities are there for religious services, and what is his or her opinion of them, and the attitude toward them by fellow members of the outfit, what do the ranks think of their enemies, their allies. Further, he should suggest to his military correspondent that those at home like to hear of the long marches, how the units fared. And for those who have been in the service since 1940 , what was their reaction to stovepipe cannon, broomstick rifles, wagons for tanks, and what do they think now. And one other subject upon which every private can write: What of the sergeant! 
Since we will soon have the largest army this country has ever had, and since the war is interrupting so many others in civilian life-what do the boys think of the army or any other branch of service as a career?

And concerning the censor: Although immediately following a transfer of troops, or a battle, certain facts can not be written for obvious military reasons, after a proper interval of time they can be, and boys might well remember this when performing their appointed roles as "historians-at-large" for their friends at home.

Of interest to friends and relatives, of value to history, and often neglected, are all the current jokes popular in camp, the new ditties being sung, and regimental songs written, and those set to music.

Many doughboy letters, of course, families, relatives, and friends will want to save for their sentimental value. But a large number of those who receive soldier mail would be happy and proud to see a copy of these letters filed in the historical records of the county, or in the War Records of the Iowa Department of History and Archives. Wherever an original letter of interest is desired saved, most County War Records Units can secure copies.

The county newspaper editors will generally be happy to cooperate in publishing from time to time the more unusual of the soldier doughboy letters. This is good for both the community and for the boy. The libraries of the county should in every instance make a card index or scrapbook of such letters published, with an alphabetical index of authors in the front of each book.

of equal interest and value to doughboy letters are service diaries. The county War Records Unit would be well advised to urge upon all families of individuals in service the wisdom of encouraging their men and women to keep a war diary. Even if nothing more than an abbreviated five-lines-a-day diary, this if kept with a degree of consistency, will become ere long a prized possession. In his diary a soldier or sailor becomes truly a personal historian, a modern Thucydides, a Twentieth 
Century Herodotus. A diary is fun, "Ask the Man who Keeps One."

A third enterprise which ought to be organized in every Iowa county is the recording in photographs of the changes and events in that area due to war. This means not merely scrapbooks of clippings, but the collection of actual photographs themselves. Either through the cooperation of the county newspapers or individual camera fans, this work can be done at a reasonable cost. Such expenses as there may be, can be met by the county Civilian Defense Council, a women's service club, a patriotic organization, the county board of supervisors, or an American Legion post.

A photographic project in a county is of two parts, one, of the civilian activities related to the war, and two, that of the county's enlisted personnel. Take the first part first. Pictures should be taken to include informal phases of the county's activities, such as the ration boards in session, salvage depots for the collection of rubber, tin, and metal filled or filling, of the actual collection of such salvage for the depots, of farmers turning once more to the use of horses, of iron lugged tractors, of boys, girls, and women handling the lines of a team or the throttle of a machine, of school groups, wherever such exist, dismissed to assist in a special crucial harvest. Excellent also for such a pictorial collection are shots of boys leaving for induction centers, of U. S. O. quarters, inside and out, of traffic on the county's highways, on the town streets, at regular intervals, of bond rallies and other special drives and war tasks. Oil stations closed or boarded up should not be neglected.

In general, with pictures as with records, the county War Records Unit should instruct that photos be taken with this question in mind: Thirty years from now, what pictures would best show what happened in the community and how it was done.

The second part of a county photographic project is the collection of photos of each of the enlisted personnel of the county. This project will appeal to all mothers, 
wives, and relatives of such individuals. Genuine helpful cooperation is easily obtained. These pictures, however, should, wherever possible, be taken in uniform, and carry on their back the name of the person, branch of service, rank, and as with all photographs, give date and place picture was taken. After a temporary display in a store or library window, these pictures should be carefully filed in the public library for the county. In such a project special care should be taken to secure pictures of all individuals from the rural areas as well as from town and city. This should be a county project with each township cooperating.

Both classes of photographs, civilian and military, should if possible be of a size $5 \times 7$ inches, or $8 \times 10$; those much larger are difficult to file without bending, and those smaller do not do justice to the individual.

These suggestions, a county war roster roll, doughboy letters, soldier diaries, and photographs of enlisted personnel and of civilian war activities, are only a few of the activities which should be thoughtfully approached by organizations in every one of Iowa's ninety-nine counties. They will appeal to all classes and all individuals in the community, and are such that if successfully adopted and carried out will leave for a future day knowledge of this transient present richer and more accurately founded than any before.

It is hoped that when the state War Records Commission is appointed and the county units are organized, that truly the record of significant events of our "present" will be thoughtfully and discriminately preserved. But work toward that end should be begun now.

\section{IV}

A strong plant needs good seed. A tall tree requires deep roots. A future of promise for any people rests upon a worthy past, worthily kept.

K. E. C. 
Copyright of Annals of Iowa is the property of State of Iowa, by \& through the State Historical Society of Iowa and its content may not be copied or emailed to multiple sites or posted to a listserv without the copyright holder's express written permission. However, users may print, download, or email articles for individual use. 